\title{
SELF CARE PRACTICES OF PATIENTS WITH LUMBAR DISC PROLAPSE IN THE POSTOPERATIVE PERIOD
}

\section{Dr. Neamat Allah Gomaa Ahmed1; Dr. Amal Bakr Abo El-Ata; Dr. Hedaya Mohamed Hendam; Sara Alasmer Mohamed}

Assistant Professor of Medical Surgical Nursing - Faculty of Nursing - Ain Shams University; Assistant Professor of Medical Surgical Nursing - Faculty of Nursing - Port Said University; Assistant Professor of Neuro-Surgical - Medicine Faculty of Medicine Azhar University (Damietta); B.Sc, Port Said University.

\begin{abstract}
Background: Self care practices affect the progress of many diseases including lumbar disc prolapse. This study aimed to assess self care practices of patients with lumbar disc prolapse in the post operative period. Setting: This study conducted at neuro-surgery department and outpatient clinic at Azhar university hospital in New Damietta city. A convenience sample of 124 adult patients diagnosed with lumbar disc prolapse were included in the study. Tool of data collection: data collected using structured interview questionnaire, it included four parts: demographic data, medical and surgical history, pain intensity and follow up and Self-care practices of patients with lumbar disc prolapse. Results: The result of present study showed that $100 \%$ of the studied patients felt pain when doing an activity and $72.6 \%$ of them had unsatisfactory self care practices in the post operative period. Conclusion: More than two third of the studied patients need improve self care practices regarding to unsatisfactory self care practices and there wasn't statistically significance relation between demographic data and self care practices. Recommendations: Design patient educational materials include proper self care practices of patients with lumbar disc prolapse in the post operative period. The health education program should be tailored every patient's individual needs .
\end{abstract}

key words : Lumbar disc prolapse, Postoperative period, Self care practices 


\section{INTRODUCTION}

Lumbar disc prolapse is a common disorder among adults with degenerated lumbar intervertebral discs (Dang \& Liu, 2010). Lumbar disc prolapse is a common disease in the spine area and it occurs in $1 \%-2 \%$ of the total population, in the U.S. about 200,000 discectomy are performed annually (Jae chul lee, 2011).

The prevalence of symptomatic herniated lumbar disc is about $1 \%$ to $3 \%$ in Finland and Italy, depending on age and sex. The highest prevalence is among people aged 30 to 50 years, with a male to female ratio of 2:1. In people aged 25 to 55 years, about $95 \%$ of herniated discs occur at the lower lumbar spine (L4/5 and L5/S1 level); disc herniation above this level is more common in people aged over 55 years (Jordan et al ; Postacchini \& Postacchini, 2011; Pouriesa, Fouladi \& Mesbahi, 2013)

Lumbar disc prolapse is a displacement of disc material (nucleus pulposus or annulus fibrosis) beyond the intervertebral disc space( Krishnan \& Krishna, 2016). The person with herniation (rupture) of a disc has not only excruciating pain but also limited mobility. These problems may in turn cause alterations in role function, coping and the ability to perform activities of daily living. (Lemon \& Burke, 2014).

Intervertebral disc prolapse disease is the most common cause of lumbar spinal surgery (Heon et al., 2013). Surgery to remove the herniated disk is performed when neurological deficit or pain is not responsive to conservative treatment or when symptoms require immediate surgical intervention (White, Duncan, Baumle, 2013).

Indications for surgical intervention on LDP appear to be generally agreed in the literature. These include: severe pain refractory to 4-6 weeks of conservative treatment, disabling pain affecting one's daily activities, cauda equina syndrome, progressive neurological deficits, associating spinal deformities (Dang \& Liu, 2010).

Self care is a concept whose time has come, as evidenced by several trends. Prior to 2014, more than 41 million nonelderly Americans were without health insurance. By necessity, self- care becomes important and highly valued. Consumers are no longer passive regarding their health; they understand the relationships of lifestyle, attitudes, and behaviors to well- being. Many health care providers and services are promoting selfcare as a strategy to reduce consumption of expensive medical services. Nurses are in a significant position to encourage individuals, families, communities, and organizations to 
build on inherent strengths, capacities, and self- care abilities (Craven et al., 2013). Also, Self-care involves both the ability to care for one self and the performance of activities necessary to achieve, maintain, or promote optimal health (Richard \& Shea, 2011).

\section{Significance of the study:}

A lot of complications may occur for patients with lumbar disc prolapse after treatment and may lead to disability due to improper self-care practice. Self-management with education of the patient about maintaining physical activities as tolerated has been encouraged for lumbar disc prolapse in the post operative period.

Self-care for patients with lumbar disc prolapse consists of specific areas such as physical self-care that include life style modification as (regular healthy diet, take medication, sleep normally without any interruption), psychological, spiritual, social and occupational self-care. It should be followed to avoid complication. During the course of treatment, the nurse needs to encourage the patients for follow up, teaching self-care practices, provide psychological support for the patient and regular assessment for any side effects, it is essential for successful treatment.

\section{AIM OF STUDY:}

This study aimed to assess self-care practices of patients with lumbar disc prolapse in the postoperative period.

\section{RESEARCH QUESTION:}

What are the self-care practices of patients with lumbar disc prolapse in the postoperative period?

\section{SUBJECTS AND METHOD:}

\section{Study Design:}

A descriptive study design was utilized in the current study.

\section{Study Setting:}

The study was conducted in neurosurgery department ( it includes 34 beds; three large wards and three small rooms) and outpatient clinic at Azhar university hospital in New Damietta city.

\section{Study Subjects:}

A descriptive study design was used. Total sample size estimated for this study of male and female adult patients in post-operative period after lumbar spine surgery (124) 
in neurosurgery department and outpatient clinic at Azhar university hospital in New

Damietta city.

\section{Sample size}

Since the prevalence of lumbar disc prolapse among patients with lumbar disc was $92 \%$ this substituting into the following equation:

$$
\begin{array}{cc} 
& Z^{2} \\
\text { Sample size }(\mathbf{n})= & \text {--.---- } \quad P(100 \text { - P) } \\
\Delta^{2} & (\text { Dobson. A., 1984) }
\end{array}
$$

Where:

$\mathbf{n}=$ sample size

$\mathbf{p}=$ prevalence of lumbar disc prolapse among patients with lumbar disc was $92 \%$

$\mathbf{Z}=$ a percentile of the standard normal distribution by $95 \%$ confidence level $=1.96$

$\Delta^{2}=$ The width of the confidence interval $=5.0$

The calculated sample size is 113 patients. Due to the expected non-participating rate (10\%), the final sample size will be $\mathbf{1 2 4}$ with lumbar disc prolapsed

\section{TOOL OF DATA COLLECTION:}

It was developed by Shahin (2013) and modified by the researcher to assess self-care practices for patients with lumbar disc prolape in the postoperative period. It included four parts :

$\operatorname{Part}(\mathbf{I})$ :

Demographic data which include (age, sex, level of education, marital status, occupation).

\section{Part (II):}

Medical and surgical history which included 6 questions .

\section{Part (III):}

Pain intensity and follow up: pain intensity (included nine questions), follow up (included one questions) .

\section{Part (V): Patient Self-Care Practices}

It included specified questions to identify detailed descriptions of the actual self-care practices performed by patients with lumbar disc prolapse after surgery in their daily living activities, this part included 9 dimensions, 43questions : personal care (included five questions), lifting (included six questions), walking (included five questions), 
sitting (included eight questions), Standing (included four questions), Sleeping (included five questions), sexual life (included three questions), social life (included two questions), Travelling (included five questions).

\section{Tool Validity:}

It was ascertained by a jury consisting of eleven experts in the nursing field from faculty of nursing, port said university and neurosurgeons from surgical department at Faculty of medicine, Mansoura University who revised the tools and modifications were done according to their opinion.

\section{Reliability:}

It was done using Cronbach alpha coefficient to assess the internal consistency of the tool and its value was 0,73 .

\section{Field Work :}

The data were collected over a period of 9 months, the actual field work was carried out from the end of December (2016) to the end of August (2017). The researcher was available 3 days/week (Saturday, Monday, and Wednesday) for 5hrs/day. The researcher interviewed the patients, the data collection was performed through meeting patients. The purpose of the study was explained by the researcher to all patients who were included in the study.

\section{Ethical consideration:}

Patient's verbal consent was obtained before data collection and after explanation of the aim of the study. Anonymity, confidentiality and privacy were asserted. The patients were informed that his or her participation in the study is voluntary and he or she can withdraw at any time.

\section{RESULTS:}

Table (1): Clarifies that, $31.5 \%$ of the studied patients were at age group from 30 to less than 40 years, $56.5 \%$ of studied patients were males, $69.4 \%$ were married. It was also found that $30.6 \%$ of the studied patients got secondary education and $46 \%$ of study patients were a laborer.

Table (2): Shows that, $75.8 \%$ of study patients didn't have any previous history of lumbar disc surgery, also, $45.2 \%$ of them had previous surgical history; 19.6 of them had a cesarean section and $14.3 \%$ had an appendectomy. 
Table (3): Illustrates that $73.4 \%$ of study patients didn't have any previous medical history.

Table (4):Shows that, regarding pain intensity, $100 \%$ of patients reported feeling pain when doing an activity, $84.7 \%$ of them reported that the pain was sever, $66.1 \%$ of them reported that they were taking painkillers when they felt pain, $62.1 \%$ of them sneezed and coughed after the operation, $97.4 \%$ of them felt pain when sneezed or coughed and $77.3 \%$ of them reported that the pain is severe . Seventy-eight percent of them drink a lot of hot drinks. $83.1 \%$ of study patients followed up periodically with the doctor.

Table (5): Illustrate that, $66.7 \%$ of them reported that taking painkiller reduce the pain, $62.7 \%$ of them were staying away from any activity or reason that provides it to reduce the pain. Also, $60 \%$ of them reported that lift heavy objects increase the pain.

Table (6): Shows that, the studied patients had an unsatisfactory level in lifting and transporting objects, sitting, sleeping, social and spiritual life and traveling and satisfactory level in periodic follow-up, personal care, walk, standing, sexuality. It also showed that $72.6 \%$ of the studied patients had unsatisfactory overall self-care practices after lumbar disc prolapse surgery

Table (7): Reveals that, there was a relation between demographic data and self-care practices. There were no statistically significant relations between them. 
Table (1): Frequency and percentage distribution of patients according to their demographic data $(n=124)$.

\begin{tabular}{|c|c|c|}
\hline Characteristics & No & $\%$ \\
\hline $\begin{array}{l}\text { Age: } \\
\qquad \begin{array}{l}20-<30 \\
30-<40 \\
40-<50 \\
50 \text { and more }\end{array}\end{array}$ & $\begin{array}{l}10 \\
39 \\
38 \\
37\end{array}$ & $\begin{array}{r}8.1 \\
31.5 \\
30.6 \\
29.8 \\
\end{array}$ \\
\hline $\begin{array}{l}\text { Min }- \text { Max } \\
\text { Mean } \pm \text { SD }\end{array}$ & & \\
\hline $\begin{array}{l}\text { Gender: } \\
\text { Male } \\
\text { Female } \\
\end{array}$ & $\begin{array}{l}70 \\
54 \\
\end{array}$ & $\begin{array}{l}56.5 \\
43.5 \\
\end{array}$ \\
\hline $\begin{array}{l}\text { Marital status: } \\
\text { Single } \\
\text { Married } \\
\text { Divorced } \\
\text { Widow } \\
\end{array}$ & $\begin{array}{c}9 \\
86 \\
10 \\
19 \\
\end{array}$ & $\begin{array}{c}7.3 \\
69.4 \\
8.1 \\
15.3 \\
\end{array}$ \\
\hline $\begin{array}{l}\text { Educational Level: } \\
\text { Illiterate } \\
\text { Read and write } \\
\text { Secondary school } \\
\text { University } \\
\text { Post-graduate }\end{array}$ & $\begin{array}{c}20 \\
35 \\
38 \\
30 \\
1\end{array}$ & $\begin{array}{c}16.1 \\
28.2 \\
30.6 \\
24.2 \\
0.8\end{array}$ \\
\hline $\begin{array}{l}\text { Job Nature: } \\
\text { Housewife } \\
\text { Laborer } \\
\text { Officer } \\
\text { Student } \\
\text { Nurse } \\
\text { Retired } \\
\text { Unemployment }\end{array}$ & $\begin{array}{c}24 \\
57 \\
32 \\
1 \\
3 \\
6 \\
1\end{array}$ & $\begin{array}{c}19.4 \\
46.0 \\
25.8 \\
0.8 \\
2.4 \\
4.8 \\
0.8\end{array}$ \\
\hline
\end{tabular}


Table (2): Frequency and percentage distribution of patient according to their surgical history $(\mathrm{n}=124)$.

\begin{tabular}{|l|c|c|}
\hline \multicolumn{1}{|c|}{ Surgical history } & No & \% \\
\hline Previous history of lumbar disk surgery & & \\
Yes & 30 & 24.2 \\
No & 94 & 75.8 \\
\hline If yes how many ?(n=30) & 21 & 70 \\
Once & 7 & 23.3 \\
Twice & 2 & 6.7 \\
Three times & 0 & 0.0 \\
Four and more & & \\
& & \\
Previous history of another surgery & 56 & 45.2 \\
Yes & 68 & 54.8 \\
No & & \\
Surgical Procedure (n= 56) & 11 & 19.6 \\
Cesarean section & 3 & 5.4 \\
Cholecystectomy & 4 & 7.1 \\
An umbilical hernia & 4 & 7.1 \\
An inguinal hernia & 2 & 3.6 \\
Varicose veins injection & 3 & 5.4 \\
Tonsillectomy & 4 & 7.1 \\
Anal fissure & 3 & 5.4 \\
Hysterectomy & 8 & 14.3 \\
Appendectomy & 3 & 5.4 \\
Removal of a sac of ovarian tissue & 2 & 3.6 \\
Thyroidectomy & 2 & 3.6 \\
Endoscope on the stomach & 1 & 1.8 \\
Remove fatty bags in the body & 2 & 3.6 \\
Hemorrhoids & 2 & 3.6 \\
Dilation and currtage & 2 & 3.6 \\
Exploring the abdomen as a result of an accident & & \\
\hline
\end{tabular}


Table (3): Frequency and percentage distribution of patients according to their medical history $(n=124)$.

\begin{tabular}{|l|c|c|}
\hline \multicolumn{1}{|c|}{ Previous medical history } & No & \% \\
\hline Post medical history co morbid diseases & 33 & 26.6 \\
Yes & 91 & 73.4 \\
No & & \\
\hline Medical history (n= 33) & 13 & 39.4 \\
Hypertension & 2 & 6.1 \\
Gastritis & 1 & 3 \\
Colitis & 3 & 9.1 \\
Irritable bowel syndrome & 1 & 3 \\
Hypercholesterolemia & 2 & 6.1 \\
High blood lipids & 2 & 6.1 \\
C virus & 2 & 6.1 \\
Fatty liver & 4 & 12 \\
Varicose legs & 2 & 6.1 \\
Cholecystitis & 1 & 3 \\
Hyperthyroidism & \multicolumn{2}{|c|}{} \\
\hline
\end{tabular}


Table (4): Frequency and percentage distribution of patients pain characteristic $(n=124)$.

\begin{tabular}{|c|c|c|}
\hline Pain intensity & No & $\%$ \\
\hline $\begin{array}{l}\text { Feeling pain when doing an activity: } \\
\text { Yes } \\
\text { No }\end{array}$ & $\begin{array}{c}124 \\
0\end{array}$ & $\begin{array}{c}100.0 \\
0.0\end{array}$ \\
\hline $\begin{array}{l}\text { If yes, the intensity of pain is : } \\
\text { Sever } \\
\text { Moderate } \\
\text { Mild } \\
\text { None }\end{array}$ & $\begin{array}{c}105 \\
17 \\
2 \\
0\end{array}$ & $\begin{array}{c}84.7 \\
13.7 \\
1.6 \\
0\end{array}$ \\
\hline $\begin{array}{l}\text { If yes, what do they do when they feel pain: } \\
\text { Going immediately to the Physician. } \\
\text { Getting rest } \\
\text { Taking painkillers. } \\
\text { Decreasing excessive effort }\end{array}$ & $\begin{array}{c}29 \\
45 \\
82 \\
3\end{array}$ & $\begin{array}{c}23.4 \\
36.3 \\
66.1 \\
2.4\end{array}$ \\
\hline $\begin{array}{l}\text { Sneezing or coughing after the operation: } \\
\text { Yes } \\
\text { No }\end{array}$ & $\begin{array}{l}77 \\
47\end{array}$ & $\begin{array}{l}62.1 \\
37.9\end{array}$ \\
\hline $\begin{array}{l}\text { If yes, feeling pain when sneezing and coughing: }(n= \\
\text { 77) } \\
\text { Yes } \\
\text { No }\end{array}$ & $\begin{array}{c}75 \\
2\end{array}$ & $\begin{array}{c}97.4 \\
2.6\end{array}$ \\
\hline $\begin{array}{l}\text { If yes, the intensity of pain is : }\left(\mathbf{n}=\mathbf{7}^{\bullet}\right) \\
\text { Severe } \\
\text { Moderate } \\
\text { Mild } \\
\text { None }\end{array}$ & $\begin{array}{c}58 \\
15 \\
2 \\
0\end{array}$ & $\begin{array}{l}77.3 \\
20.0 \\
2.7 \\
0.0\end{array}$ \\
\hline $\begin{array}{l}\text { If yes, measures to reduce this pain: }(\mathbf{n}=\mathbf{7 5}) \\
\text { Drinking a lot of liquids. } \\
\text { Breathing exercises. } \\
\text { Inhaling by Daphne air (steam). } \\
\text { Taking medicine for coughing. } \\
\text { Consulting the doctor. }\end{array}$ & $\begin{array}{c}59 \\
4 \\
4 \\
54 \\
5\end{array}$ & $\begin{array}{c}78.7 \\
5.3 \\
5.3 \\
72.0 \\
6.7\end{array}$ \\
\hline $\begin{array}{l}\text { Periodic follow-up } \\
\text { Yes } \\
\text { No }\end{array}$ & $\begin{array}{c}103 \\
21\end{array}$ & $\begin{array}{l}83.1 \\
16.9\end{array}$ \\
\hline
\end{tabular}


Table (5): Frequency distribution of Factors that relieve and increase the pain $(n=75)$ :

\begin{tabular}{|l|c|c|}
\hline Factors that relieve and increase the pain $\mathbf{( n = 1 2 4 )}$ & No & \% \\
\hline Factors relieve the pain: & & \\
Painkillers & 50 & 66.7 \\
Taking a rest. & 33 & 44.0 \\
Staying away from any activity or reason it & 47 & 62.7 \\
provides. & & \\
Taking the right posture. & 23 & 30.7 \\
Reducing the weight & 2 & 2.7 \\
Trying not to sneeze and cough & 5 & 6.7 \\
Exercise & 0 & 0.0 \\
& & \\
& & \\
& & \\
Factors increase the pain : & 45 & 60.0 \\
Lifting heavy objects & 35 & 46.7 \\
Standing for a long time & 7 & 9.3 \\
Walking long distances & 26 & 34.7 \\
Sitting for a long time & 28 & 37.3 \\
Exposure to sneezing or coughing & 3 & 4.0 \\
All of the above & 1 & 1.3 \\
Obesity & 2 & 2.6 \\
Bending the lower limb for a long time & & \\
& \\
\hline
\end{tabular}

Table (6): Overall Self-care practices of patients with lumbar disc prolapse after surgery $(\mathrm{n}=124)$.

\begin{tabular}{|c|c|c|c|c|c|}
\hline & \multicolumn{2}{|c|}{ Unsatisfactory } & \multicolumn{2}{|c|}{ Satisfactory } & \multirow[t]{2}{*}{ Mean \pm SD. } \\
\hline & No. & $\%$ & No. & $\%$ & \\
\hline Periodic follow-up & 21 & 16.9 & 103 & 83.1 & $83.06 \pm 37.66$ \\
\hline Personal care & 57 & 46.0 & 67 & 54.0 & $54.75 \pm 26.40$ \\
\hline Lifting and transporting objects & 102 & 82.3 & 22 & 17.7 & $44.94 \pm 21.60$ \\
\hline Walk & 17 & 13.7 & 107 & 86.3 & $82.95 \pm 18.90$ \\
\hline Sitting & 124 & 100.0 & 0 & 0.0 & $42.38 \pm 9.23$ \\
\hline Stand & 12 & 9.7 & 112 & 90.3 & $81.18 \pm 19.47$ \\
\hline Sleep & 124 & 100.0 & 0 & 0.0 & $22.93 \pm 6.70$ \\
\hline Sexuality & 36 & 29.0 & 88 & 71.0 & $63.71 \pm 41.65$ \\
\hline Social and Spiritual Life & 103 & 83.1 & 21 & 16.9 & $35.35 \pm 24.47$ \\
\hline Travel & 71 & 57.3 & 53 & 42.7 & $54.69 \pm 10.56$ \\
\hline Overall & 90 & 72.6 & 34 & 27.4 & $47.75 \pm 10.10$ \\
\hline
\end{tabular}


Table (7): Relation between self-care practices and demographic data of the studied patients.

\begin{tabular}{|c|c|c|c|c|c|c|}
\hline & \multicolumn{4}{|c|}{ Overall Practice } & \multirow{3}{*}{$\chi^{2}$} & \multirow{3}{*}{$\mathbf{p}$} \\
\hline & \multicolumn{2}{|c|}{$\begin{array}{l}\text { Unsatisfactory } \\
\quad(\mathbf{n}=90)\end{array}$} & \multicolumn{2}{|c|}{$\begin{array}{c}\text { Satisfactory } \\
\quad(\mathbf{n}=\mathbf{3 4})\end{array}$} & & \\
\hline & No. & $\%$ & No. & $\%$ & & \\
\hline \multicolumn{7}{|l|}{ Age } \\
\hline $20-<30$ & 9 & 10.0 & 1 & 2.9 & \multirow{4}{*}{4.783} & \multirow{4}{*}{0.188} \\
\hline $30-<40$ & 27 & 30.0 & 12 & 35.3 & & \\
\hline $40-<50$ & 24 & 26.7 & 14 & 41.2 & & \\
\hline 50 and more & 30 & 33.3 & 7 & 20.6 & & \\
\hline \multicolumn{7}{|l|}{ Gender } \\
\hline Male & 50 & 55.6 & 20 & 58.8 & \multirow{2}{*}{0.107} & \multirow{2}{*}{0.743} \\
\hline Female & 40 & 44.4 & 14 & 41.2 & & \\
\hline \multicolumn{7}{|l|}{ Marital status } \\
\hline Single & 8 & 8.9 & 1 & 2.9 & \multirow{4}{*}{4.985} & \multirow{4}{*}{$\begin{array}{l}{ }^{{ }^{\mathrm{CC}}} \mathrm{p}= \\
0.171\end{array}$} \\
\hline Married & 57 & 63.3 & 29 & 85.3 & & \\
\hline Divorced & 9 & 10.0 & 1 & 2.9 & & \\
\hline Widow & 16 & 17.8 & 3 & 8.8 & & \\
\hline \multicolumn{7}{|l|}{ Educational Level } \\
\hline Illiterate & 15 & 16.7 & 5 & 14.7 & \multirow{7}{*}{1.309} & \multirow{7}{*}{$\begin{array}{l}{ }^{{ }^{\mathrm{MC}}} \mathrm{p}= \\
0.990\end{array}$} \\
\hline Read and write & 9 & 10.0 & 5 & 14.7 & & \\
\hline Primary school & 7 & 7.8 & 2 & 5.9 & & \\
\hline Preparatory school & 9 & 10.0 & 3 & 8.8 & & \\
\hline Secondary school & 27 & 30.0 & 11 & 32.4 & & \\
\hline University & 22 & 24.4 & 8 & 23.5 & & \\
\hline Post-graduate & 1 & 1.1 & 0 & 0.0 & & \\
\hline \multicolumn{7}{|l|}{ Job Nature } \\
\hline House wife & 19 & 21.1 & 5 & 14.7 & \multirow{7}{*}{6.073} & \multirow{7}{*}{$\begin{array}{l}{ }^{{ }^{\mathrm{MC}}} \mathrm{p}= \\
0.383\end{array}$} \\
\hline Laborer & 44 & 48.9 & 13 & 38.2 & & \\
\hline Officer & 20 & 22.2 & 12 & 35.3 & & \\
\hline Student & 1 & 1.1 & 0 & 0.0 & & \\
\hline Nurse & 1 & 1.1 & 2 & 5.9 & & \\
\hline Retired & 4 & 4.4 & 2 & 5.9 & & \\
\hline Unemployment & 1 & 1.1 & 0 & 0.0 & & \\
\hline
\end{tabular}

$\chi^{2}, p: \chi^{2}$ and $p$ values for Chi square test

${ }^{\mathrm{MC}} \mathrm{p}$ : $\mathrm{p}$ value for Monte Carlo for Chi square test

\section{DISCUSSION:}

Lumbar disc prolapse is considered to be one of the most common causes of a low backache in the world. It is considered to be the most common cause of disability above the age of 45 years and the second most common cause for seeking physicians (Khodair, Gheida \& Eltomy, 2014). 
Lumbar disc prolapse surgery is most commonly performed electively in patients where conservative therapies have failed to gain improvement of leg pain and disability. Only in rare cases, acute surgery needs to be performed, e.g. when a large disc prolapse result in cauda equina syndrome (Silverplats et al., 2010). Surgery for lumbar disc prolapse was cost-effective. The total costs for surgery were lower due to lower recurrence rates and fewer disability benefits, and surgery improved quality of life much more than nonsurgical treatments Hansson \& Hansson, (2007). Annually many patients suffering from pain, disability and acute disorders in daily activities arising from disc prolapse go under operations (Aghayee, Azhari \& Heidarnejad, 2014).

Regarding demographic data of the studied patients, the results revealed that more than the half of studied patients were males. This may be related to the nature of occupation in which nearly half of study patients were laborer who was engaged in hard work that requires heavy lifting and twisting of the back. As well, the present study shows that less than one-third of studied patients were at age 30 to less than 40 years old and the same proportion was from 40 to less than 50 years old.

Regarding the relation between age group and self-care practices, the findings revealed that the self-care practices, of younger age group patients, were more satisfactory than those of the older age group. On the view of the researcher, this might be that the young patients are in the productive life, engaged in work and responsibilities, which force them to go back their work and continue their social roles.

Incorrect use of body mechanics was found to be responsible for low back pain aggravation. Improper lifting technique causes weight bearing on back muscles and increases the intradiscal pressure. To note the results of the present study revealed that more than two-fifths of the studied patients were laborer who is usually engaged in heavy manual tasks which demand more carrying, lifting and persistent bending. From the researcher " point of view", these activities act as a cumulative load on the spine which leads to acceleration of occurrence of lumbar disc prolapse.

Less than the half of the studied patients were illiterate, write and read. A similar finding was reported by Patrick, Tamara, William, (2011) who said that limited educational attainment has been associated with many diseases, including lumbar disc prolapse, other health-compromising behaviors, and lack of adherence to treatment regimen. So,it was 
seen that the secondary and university graduated patients had a satisfactory level of selfcare practices which is significantly more than those who had basic education or those with no formal education or illiterate patients.

About third quarter of them reported that lifting heavy objects increase the pain, all of them reported that taking painkiller reduce the pain, more than two third of them were taking rest, two third of them were Staying away from any activity or reason it provides to reduce the pain. More than two third of them had unsatisfactory self-care practices of lifting and transporting objects. Also, this is similar to the results of the study of (Shahin, 2013).

In this respect, Gupta et al., (2015) said in their study that prolonged sitting may be a risk factor for developing LBP. Possible mechanisms for a causal relationship between prolonged sitting and LBP are increased intra-discal pressure, the stiffness of the lumbar spine, reduced the strength of the lower back muscles. Regarding sitting table, incorrect sitting posture tends to increase low back pain (LBP), also sitting time is positively associated with LBP intensity. This could be attributed to the lack of back support and lack of weight distribution on thighs as well as back spine muscles.

With this context, All of the studied patients had unsatisfactory self-care practices of sitting. From the researcher "point of view", this might be due to the improper sitting may be attributed to the study subject working either office employees or drivers who spend a lot of time sitting on a chair combined with lack of information regarding proper use of body mechanics during sitting.

The majority of them had satisfactory self-care practices of standing. From the researcher "point of view", this may be due to the period after the surgery isn't enough to make the patient can stand for a long time.

In relation to self-care practices of sleeping, sleep is an important part of our lives, with approximately one-third of our life spent sleeping. The type of mattress and pillow an individual is using will greatly impact their quality of sleep as well as their pain. In order to maintain a straight spine, both the mattress and pillow an individual sleeps on can impact whether the spine remains neutral, with not enough support and too much support both negatively impacting spinal alignment. In regards to mattresses, it was 
concluded that medium-firm mattresses provide the best outcome for increased sleep quality and for reducing pain (Fees et al., 2015).

All of the studied patients had unsatisfactory self-care practices of sleeping. Also, Nettina, (2016) agree with the researcher's results, who said that the back can be gently stretched by lying on the back and bringing the knees up towards the chest in the same time he disagrees with the researcher's result in which he said that the patient should avoid the prone position although during data collections some patients preferred sleeping on the abdomen and prefer sleeping on the abdomen during physiotherapy. On the view of the researcher, pain may be due to doing self-care practices of sleeping properly.

Sexuality is an important aspect of human life. Sexual activity may be affected by lumbar disc herniation through different mechanisms, lumbar disc herniation has negative effects on sexual life (Akbas et al., 2010). More than two third of the studied patients had satisfactory self-care practices of sexuality. This is in agreement with Shahin, (2013) who showed that nearly two-thirds of the studied patients of her study avoid sexual relation when feeling back pain. Nearly a half of the patients sleep either on the back or on the side during sexual relation.

More than three- quarters of the studied patients had unsatisfactory social and spiritual life, From the researcher "point of view", this may be due to the pain that results from sitting, standing for a prolonged period. More than the half of the studied patients had unsatisfactory self-care practices of traveling.

This study showed that more than two third of the studied patients had an unsatisfactory level of self-care practices and more than one fourth had a satisfactory level. From the researcher "point of view", this may be due to lack of the health education about self care practices in the postoperative period. Also, it revealed that there is a relationship between personal data and self-care practices Alodaibi., Minick \& Fritz, (2012) said that more than one-third of the patients undergoing discectomy were not satisfactory and more than one quarter continue to have significant residual pain after surgery.

Patients with lumbar disc prolapse should understand that following instruction in the form of proper body mechanics during everyday life in sitting, standing, walking sleeping, lifting objects and sexual relationship can improve self-care practices and reduce disability. 
According to self-care practices score, the present study showed that most of the studied patients had unsatisfactory self-care practices. This indicates the need for more reinforcement of the nurse's role in health care instruction in collaboration with the treating physician and giving this instruction to the patients and encourage them to follow up. This will assist patients to become an active participant in their own care and to ensure that patients have the necessary self-care practices to prevent either occurrence or recurrence of disc prolapse.

\section{CONCLUSION:}

Based on the findings of the current study, more than two third of the studied patients had unsatisfactory self care practices. There was relation between demographic data and self care practices but there was no statically significance relation between them.

\section{RECOMMENDATIONS:}

\section{Based on the findings of the current study, the recommendations were:}

- Design patient educational materials to present more comprehensive information, including proper self care practices of patients with lumbar disc prolapse in the post operative period.

- The health care team should establish a regular follow up system with the patients to assure their understanding and practicing what they need to know and do.

\section{REFERENCE:}

Aghayee, H.N., Azhari, S.H., \& Heidarnejad, F. (2014): The Outcomes of Surgical Treatment of Recurrent Lumbar Disk Herniation with Discectomy Alone and Discectomy with Posterolateral Interbody Fusion. Novel Biomed, 2(1);10-17. 
Akbas, N.A., Dalbayrak, S., Kulcu, D.G., Yilmaz, M., Yilmaz, T., Naderi, S. (2010): Assessment of sexual dysfunction before and after surgery for lumbar disc herniation. . Journal of Neurosurgery: Spine, 13(5); 581-586.

Alodaibi, F.A., Minick, K.I., Fritz, J.M.(2012): Do preoperative fear avoidance model factors predict outcomes after lumbar disc herniation surgery? A systematic review. The Official Journal of the Society .31(5); 196-203.

Craven, R. F., Hirnle, C.J., Henshaw, C.H.M.(2013). Fundamentals of Nursing. Human Health and Function. New York. Wolters Kluwer. P.705

Dang, L., Lui, Z. (2010): A review of current treatment for lumbar disc herniation in children and adolescents. Eur Spine J, 19(2),205-214.

Dobson, A. (1984): Calculating sample size, Trans Menziez Foundation 75- 79.

Fees, F., James, D., Mayers, J., Murphy, J., Rooney, M., Taylor, J., Torrii, L. (2015): effect of mattresses and pillow designs on promoting sleep quality, spinal alignment and pain reductio nin adults: systematic reviews of controlled trials. Microform ed, Pro Quest LLC. Pp.2-7.

Gupta, N .,Christiansen, C,S., Hallman, D,M., Korshoj, M., Carneiro, I,G., Holtermann, A. (2015): Is Objectively Measured Sitting Time Associated with Low Back Pain? A Cross-Sectional Investigation in the nomad study. journal. pone plos. One tenth annirversary., 10(3);p. 0121159.

Hansson, E., Hansson, T.(2007): The cost-utility of lumbar disc herniation surgery. European Spine Journal. 16(3); 329-337.

Heon, K.C., Seon, P.C., Boram, C., Jung, K.M., Joo, B. (2013): Reoperation Rate After Surgery for Lumbar Herniated Intervertebral Disc Disease. Nationwide Cohort Study. Spine , 28(7),581-590.

Jae chul lee, M.D. (2011): Conservative Treatment of Lumbar Disc Herniation. Korean Society of spine surgery ,18(3),123- 13. 
Jordan, J.L., Konstantinou, K., O'Dowd, J.(2011): Herniated lumbar disc. PMC; $38(4) 279$.

Khodair, S.A., Ghieda, U.E., Eltomey, M.A. (2014): Relationship of lumbosacral spine morphometrics and lumber disc degenerative disease in young adults using magnetic resonance imaging. The Egyptian Journal of Radiology and Nuclear Medicine, 45(7),461466.

Krishnan, R.N., Krishna, S.G. (2011): Intervertebral disc pathology and ayurveda. International Ayurvedic medical Journal.4(10),3036-3045.

Lemon, P., Burke , K. (2014): Medical-Surgical Nursing Critical thinking for reason - centered care. $2^{\text {nd }}$ ed , Australia , pearson. Pp.1581-1584.

Nettina, S.M. (2016): Lippincott Manual Of Nursing Practice. $10^{\text {th }}$ ed., New York. Wolters Kluwer. P. 569.

Patrick, R., Tamara, S., William, A. (2011): Lumbar disc herniation in the spine patient outcomes research trial. Eur spine J. 36(11);1-9.

Postacchini, F., Postacchini, R. (2011): Operative Management of Lumbar Disc Herniation Neurosurgical . Springer, Vienna;108(4): 17-21

Pouriesa, M., Fouladi, R.F \& Mesbahi, S. (2013): Disproportion of end plates and the lumbar intervertebral disc herniation. Spine J, 13(4):402- 407.

Richard, A.A., Shea, K. (2011): Delineation of Self-Care and Associated Concepts . Journal of nursing scholarship. 43(3):255-264.

Shahin, S.R. (2013): self care practices of patients with lumbar disc prolapse in relation to their post treatment disability levels .journal of neurosurgery. Master's Thesis. Faculty of Nursing. University of Alexandria.

Silverplats, K. (2010): Long-term outcome of lumbar disc herniation surgery Studies on different influencing factors. Published master's thesis. University of Gothenburg, Sweden. 
White, L ., Duncan, G., Baumle, W. ( 2013) : Medical-Surgical Nursing An Integrated Appraoch. $3^{\text {rd }}$ ed, United State Of America, Delmar , P. 293.

مـمارسـات الـرعـايـة الـذاتـــة لمـرضي الانـزلاق الـضضروفي القطـني في فتـرة مـا بــد الـجر احسة

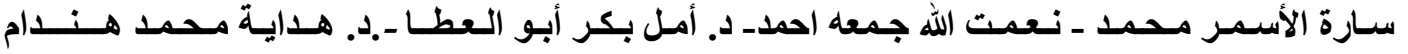

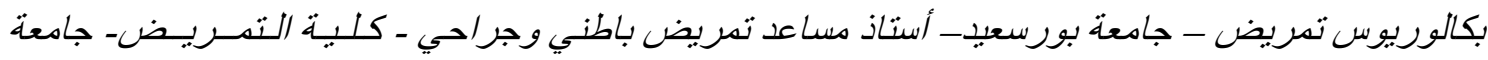
عبن شهس، أستاذ مساعد تمريض باطني وجراحي ـ كلية التمريض - جامعة بورسعيد _/ستاذ مساعد جراحة

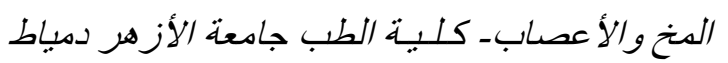

\section{السخـلاصــة}

تؤثر ممارسات الرعاية الذاتية على تقدم العديد من الأمر اض بما في ذلك الانزلاق الغضروفي القطني.. تهدف هذه الـاراسـة إلي تقييم ممارسات الر عاية الذاتية لدي مرضي الانزلاق الغضروفي القطني في فترة ما بعد الجر احة. وقد أجريت هذه الجراحة علي ؛ ؟ من مرضي الانزلاق الغضروفي القطني في فترة ما بعد الجراحة في العيادات الخارجية وكذلك قسم جر احة المخ و الأعصاب بمستشفي الأز هر الجامعي بدمياط الجديدة. وقد تم استخدام أداة تتكون من أربعة أجزاء لجمع هذه البيانات : الجزء الأول: عبارة عن استمارة لتجميع البيانات الثخصية ،الجزء الثاني: التاريخي المرضي و الجراحي ،الجزء الثالث: شدة الألم والمتابعة الدورية والجزء الرابع: عبارة عن مقياس لتقيبم

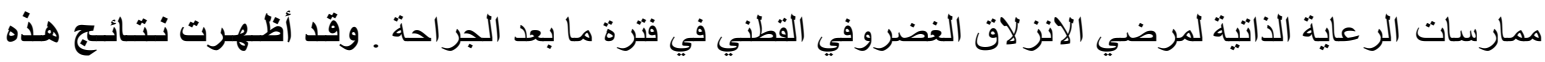

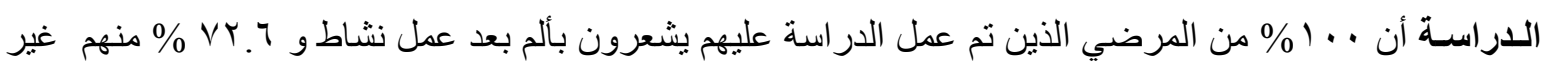
مرضيين من ممارسات الرعاية الذاتية في فترة ما بعد الجراحة، وانه يوجد علاقة غير دالة بين البيانات الشخصية

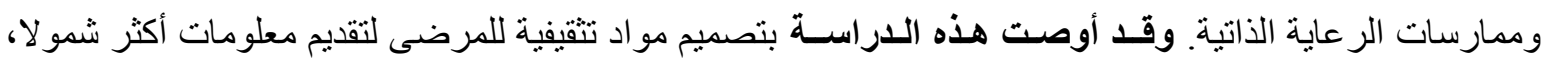
بما في ذللك ممارسات الرعاية الذاتية المناسبة في فترة ما بعد الجراحة وكذللك عمل برنامج تعليمي صحي للاحتياجات الفردية لكل مريض .

الكلمات المرشدة : الانز لاق الغضروفي القطني، فترة ما بعد الجراحة، ممارسات الرعاية الذاتية. 